\title{
PENYULUHAN HUKUM DOUBLE TRACK SISTEM (SANKSI PIDANA DAN TINDAKAN)TERHADAP PENYALAHGUNAAN NARKOTIKA BAGI MASYARAKAT DESA BANDAR SONO KABUPATEN BATUBARA
}

\author{
Sri Sulistyawaty), Iwan Setyawan'), Nelvitia Purba ${ }^{3)}$, \\ Lukman Harun Siregar ${ }^{4)}$ \\ Universitas Muslim Nusantara Al Washliyah ${ }^{1)}$ \\ Universitas Muslim Nusantara Al Washliyah ${ }^{2)}$ \\ Universitas Muslim Nusantara Al Washliyah ${ }^{3)}$ \\ Universitas Muslim Nusantara Al Washliyah ${ }^{4}$
}

\begin{abstract}
ABSTRAK
Kabupaten Batu Bara terletak di daerah pinggiran pantai yang memiliki Pelabuhan namun pelabuhan-pelabuhan yang ada di Sumatera Utara ini banyak juga terdapat Pelabuhan yang ilegal yang pengawasan di garis pantai tersebut yang relatif lemah. Propinsi Sumatera Utara merupakan salah satu daerah yang dekat dengan Malaysia karena Narkoba tersebut mayoritas berasal dari luar negeri . Masa modren saat ini dengan mudahnya untuk mendapatkan barang haram tersebut dari oknum-oknum yang tak bertanggung jawab. Penanggulangan Penyalahgunaan Narkotika diperlukan upaya yang terpadu dan Komprehensif meliputi : Preventif, Represif, Terapi Dan Rehabilitasi.Tindakan Preventif yang dilakukan salah satunya dengan Penyuluhan Hukum yang berkaitan dengan Bahaya Narkoba dan apa itu sebenarnya Double Track Sistem yang belum dipahami oleh masyarakat. Metode Pelaksanaan antara lain Mengidentifikasi Kebutuhan Sosialisasi Sebelum Kegiatan dilaksanakan akan dilakukan identifikasi terhadap kebutuhan dan potensi -potensi untuk penyelenggarakan Kegiatan Penyuluhan Hukum ini , yang meliputi tenaga ahli (Pelatih dan Narasumber). Menyusun Desain penyuluhan Hukum Desain sosialisasi ini mencakup gagasan dan rencana Penyuluhan Hukum ini di Kabupaten Batubara ini terletak di pinggir Pantai. Kegiatan Pengabdian Kepada Masyarakat ini adalah merupakan salah satu Gerakan Kampanye menolak penyalahgunaan Narkotika sudah menjadi Program Pemerintah di Indonesia pada umumnya dan Sumatera Utara pada khususnya Penyalahgunaan Narkotika merupakan kategori sebuah tindak kejahatan yang luar biasa (extraordinary crime), oleh karena itu perlu ditangani secara intensif. Strategi pemberantasan Penyalahgunaan Narkotika ini terdapat tiga unsur yang utama antara lain :Pencegahan, Penindakan dan Peran Masyarakat.Pencegahan yang dilakukan kepada masyarakat dengan bersifat intensif mengadakan Penyuluhan Hukum yang merupakan satu satu Kegiatan Tri Darma Perguruan Tinggi dengan melakukan Pengabdian Kepada Masyarakat.
\end{abstract}

Kata Kunci: Pencegahan, Kejahatan Narkoba, Double Track Sistem, Pinggiran Pantai

\begin{abstract}
Batu Bara Regency is located in a coastal area that has a harbor, but there are many ports in North Sumatra that have illegal ports that are relatively weak in monitoring the coastline. North Sumatra Province is one of the areas close to Malaysia because the majority of these drugs come from abroad. The current modern period is easy to get these illicit goods from irresponsible elements. Prevention of Narcotics Abuse requires integrated and comprehensive efforts that include: Preventive, Repressive, Therapy and Rehabilitation. Preventive measures are carried out one of them with Legal Education relating to the Dangers of Drugs and what exactly is Double Track System that is not yet understood by the public. Implementation Methods include identifying the Socialization Needs Before the Activities are carried out, identification of the needs and potentials for conducting Legal Counseling Activities will be carried out, which includes experts (Trainers and Speakers). Arranging the legal counseling design This socialization design includes the ideas and plans for this legal counseling in Batubara Regency, located on the coast. This Community Service Activity is one of the Campaign Movements against Narcotics abuse which has become a Government Program in Indonesia in general and North Sumatra, in particular, Narcotics Abuse is a category of extraordinary crimes, and therefore needs to be dealt intensively. This narcotics abuse eradication strategy has three main elements, among others: Prevention, Enforcement and the Role of the Community. Prevention is carried out to the community intensively in conducting
\end{abstract}


Legal Education which is one of the Tri Darma Activities of Higher Education by doing Community Service.

Keywords: Prevention, Drug Crimes, Double Track System, Coastal

\section{PENDAHULUAN}

Penyalahgunaan Narkotika merupakan bahaya yang dapat menghambat kemajuan bangsa Indonesia dalam melaksanakan pembangunan di setiap sektor kehidupan. Dimana kita ketahui bahwa Indonesia pada dekade 70-an belum lagi menjadi daerah yang menggiurkan bagi pemasaran narkotika. Pada saat itu, negeri ini hanya merupakan wilayah transit bagi barang-barang haram yang akan dikirim ke Australia atau ke Negara Asia Pasifik lainnya. Namun dua dasa warsa kemudian, Indonesia sudah menjadi pasar yang menggiurkan bagi para pengedar narkotika. Bahkan disebut-sebut menjadi produsen barang yang bisa membuat perasaan melayang-layang itu. [1]

Permasalahan yang dihadapi saat ini adalah yang berkaitan dengan narkotika adalah bahwa Sumatera Utara menempati ranking ketiga setelah DKI Jakarta dan Kalimantan Timur dalam tingkat pemakai narkoba. [2]

Di Kabupaten Batubara merupakan salah satu Kabupaten yang ada di Sumatera Utara yang berada dipinggir Pantai Di Kabupaten Batubara merupakan salah satu Kabupaten yang ada di Sumatera Utara yang berada dipinggir Pantai. Secara Geografis Kabupaten Batu Bara merupakan sebuah kawasan di bahagian Timur dari Propinsi Suamtera Utara.Sebelah Timur berbatasan dengan Selat Malaka dan Kabupaten Asahan, Sebelah Selatan berbatasan dengan Kabupaten Asahan dan kabupaten Simalungun, sebelah Barat berbatasan dengan kabupaten Serdang bedagai sebelah Utara berbatasan dengan Selat Malaka.Oleh karena sebahagian dari wilayah ini berada dipinggiran laut, dan oleh karena itu nelayan menjadi mata pencaharian utama, disamping pertanian dan perkebunan .Kabupaten Batu Bara saat ini berada dalam kondisi yang meprihatinkan nasib generasi penerus bangsa terutama remaja, peredaran Narkoba sudah merasuki sendi-sendi bangsa dan melemahkan semangat juang belajar menuntu ilmu bagi generasi muda kalangan pemuda yang ratarata masih duduk dibangku SMP dan SMA. Pada masa sekarang ini para bandar dan agen mempermudah cara untuk mendapat/menggunakan Narkoba hanya bermodal uang RP 20.000,- kalangan remaja sudah dapat menikmati barang haram tersebut sehingga, sehingga hal ini tidak rasa umum lagi di Batubara khususnya kecamatan Tanjung Tiram dalam hal peredaran narkoba Psikotropika jenis Sabusabu.Dampak dari peredaran Narkoba ini membuat keresahan masyarakat, hal ini disebabkan karena segala sesuatu yang dapat dijual seperti : perabot, ternak menjadi sasaran pengguna Narkoba untuk dijadikan modal guna membeli keperluan narkoba tersebut.[3]

Penyalahgunaan Narkotika di Indonesia sudah sampai ketingkat yang sangat mengkhawatirkan. Menurut Menhuk dan HAM Amir Syamsuddin. Berdasarkan data Kemenhuk dan HAM pada tahun 2011 tercatat penggagalan 98 kasus 
penyeludupan narkoba di dalam Lembaga Pemasyarakatan. Sedangkan tahun 2012 baru mengungkap 12 kasus narkoba. Permasalahan yang terjadi bahwa Lembaga pemasyarakatan di Indonesia adalah salah satu pasar bagi pengedar narkoba. Pemakai narkoba banyak di tahan di Lembaga Pemasyarakatan mereka rata-rata memiliki uang. Hal ini menyebabkannya seringkali mereka belum dalam kondisi sembuh tapi masih ketergantungan pada narkoba. Permasalahan yang terjadi saat ini kita menganggap kalau pemakai narkoba itu memiliki karakter seperti penjahat biasa sehingga bisa di campur dengan narapidana lainnya. Padahal mereka yang memakai narkoba adalah dalam kondisi ketergantungan obat yang sakit secara fisik dan psikologis. Mereka membutuhkan rehabilitasi medis untuk memulihkan kondisinya. Saat dimasukkan Lembaga Pemasyarakatan tanpa ada terapi medis maka ini tidaklah menyelesaikan masalah mereka karena mereka dalam kondisi ketergantungan obat.

Upaya untuk melakukan Sidak pada pengguna narkotika di Lembaga Pemasyarakatan hanya akan menghentikan kegiatan ini sementara. Akar permasalahannya justru pada adanya permintaan narkoba yang cukup besar dan adanya penawaran untuk itu terutama Kabupaten Batubara banyak pelabuhan illegal transit. Gerakan Kampanye menolak penyalahgunaan Narkotika sudah menjadi Program Pemerintah di Indonesia pada umumnya dan Sumatera Utara pada khususnya Penyalahgunaan Narkotika merupakan kategori sebuah tindak kejahatan yang luar biasa (extraordinary crime) ,oleh karena itu perlu ditangani secara intensif. Strategi pemberantasan Penyalahgunaan Narkotika ini terdapat tiga unsur yang utama antara lain :Pencegahan, Penindakan dan Peran Masyarakat.

Double Track Sistem terhadap pelaku kejahatan Narkoba perlu diadakan untuk penyuluhan hukum untuk memberikan pencerahan pada masyarakat yang ada di Desa Bandar Sono Kecamatan Nibung Hangus Kabupaten Batu Bara untuk menghindari dari barang haram ini yaitu Narkoba mengingat Hukuman yang diberikan sangat berat sesuai dengan Undang Undang nomor 35 Tahun 2009.

\section{METODE PELAKSANAAN}

Didalam melaksanakan kegiatan Pengabdian Kepada Masyarakat ini metode yang digunakan adalah melalui kegiatan ceramah, diskusi dan tanya jawab tentang permasalahan yang berkaitan dengan Double Track Sistem terhadap para pelaku kejahatan penyalahgunaan narkotika dan pencegahan Penyalahgunaan Narkotika. Pada kegiatan sosialisasi ini juga diajarkan bagaimana cara mendeteksi secara dini seseorang yang terkena narkoba dengan melihat ciri-cirinya yang dikemas dalam bentuk power point. Sehingga Pada hari yang telah ditentukan Tim Pengabdian Masyarakat dari LP2M UMN AW melaksanakan kegiatan Pengabdian Kepada Masyarakat Dalam Bentuk Penyuluhan Hukum di Desa Bandar Sono Kecamatan Nibung Hangus Kabupaten Batu Bara dan dilanjutkan dengan MOU antara Desa ini dengan UMN Al Washliyah Medan. 
Metode Pendekatan Yang DiTawarkan Untuk Menyelesaikan Persoala ini antara lain :

A. Mengidentifikasi Kebutuhan Untuk Melaksanakan Kegiatan Penyuluhan Hukum

Sebelum Kegiatan dilaksanakan akan dilakukan identifikasi terhadap kebutuhan dan potensi -potensi untuk penyelenggarakan Penyuluhan Hukum ini di Desa Bandar Sono Kecamatan Nibung Hangus Kabupaten Batu Bara Materi - materi Penyuluhan Hukum yaitu : meliputi tenaga ahli (Pelatih dan Narasumber).

B. Menyusun Desain Sosialisasi Desain Penyuluhan ini Di Desa Bandar Sono Kecamatan Nibung Hangus di

Kabupaten Batubara ini terletak di pinggir Pantai.

C. Menyusun Bahan /Materi penyuluhan Hukum

Bahan yang perlu dipersiapkan dengan cara antara lain :

1. Menetapkan nama-nama Narasumber yang dilibatkan dalam kegiatan Penyuluhan Hukum ini.

2. Melakukan diskusi dengan seluruh Narasumber untuk mengorientasi mereka tentang Kegiatan Penyuluhan Hukum yang akan dilaksanakan dan peran mereka dalam kegiatan Penyuluhan Hukum tersebut.

3. Meminta kepada setiap Narasumber untuk bertanggung jawab terhadap terhadap materi yang ditugaskan kepadanya.

4. Mengadakan persiapan untuk kegiatan Penyuluhan Hukum ini
Hal-hal yang perlu dipersiapkan berkenaan dengan kegiatan Penyuluhan Hukum ini yang dipersiapkan adalah : Materi yang terkait dengan akomodasi, logistik dan persuratan.

\section{HASIL \& PEMBAHASAN}

Secara Geografis Kabupaten Batu Bara merupakan sebuah kawasan di bahagian Timur dari Propinsi Suamtera Utara.Sebelah Timur berbatasan dengan Selat Malaka dan Kabupaten Asahan, Sebelah Selatan berbatasan dengan Kabupaten Asahan dan kabupaten Simalungun, sebelah Barat berbatasan dengan kabupaten Serdang bedagai sebelah Utara berbatasan dengan Selat Malaka.Oleh karena sebahagian dari wilayah ini berada dipinggiran laut, dan oleh karena itu nelayan menjadi mata pencaharian utama, disamping pertanian dan perkebunan .Kabupaten Batu Bara saat ini berada dalam kondisi yang meprihatinkan nasib generasi penerus bangsa terutama remaja, peredaran Narkoba sudah merasuki sendi-sendi bangsa dan melemahkan semangat juang belajar menuntu ilmu bagi generasi muda kalangan pemuda yang ratarata masih duduk dibangku SMP dan SMA.

Akar permasalahannya justru pada adanya permintaan narkoba yang cukup besar dan adanya penawaran untuk itu terutama Kabupaten Batubara banyak pelabuhan illegal transit. Gerakan Kampanye menolak penyalahgunaan Narkotika sudah menjadi Program Pemerintah di Indonesia pada umumnya dan Sumatera Utara pada khususnya Penyalahgunaan Narkotika merupakan kategori 
sebuah tindak kejahatan yang luar biasa (extraordinary crime) ,oleh karena itu perlu ditangani secara intensif. Strategi pemberantasan Penyalahgunaan Narkotika ini terdapat tiga unsur yang utama antara lain :Pencegahan, Penindakan dan Peran Masyarakat.Pencegahan yang dilakukan kepada masyarakat dengan bersifat intensif mengadakan Penyuluhan Hukum yang merupakan satu satu Kegiatan Tri Darma Perguruan Tinggi dengan melakukan Pengabdian Kepada Masyarakat.

Double Track Sistem terhadap pelaku kejahatan Narkoba perlu diadakan untuk penyuluhan hukum untuk memberikan pencerahan pada masyarakat yang ada di Desa Bandar Sono Kecamatan Nibung Hangus Kabupaten Batu Bara untuk menghindari dari barang haram ini yaitu Narkoba mengingat Hukuman yang diberikan sangat berat sesuai dengan Undang Undang nomor 35 Tahun 2009.
Pencegahan Penyalahgunaan Narkoba selama ini dilakukan terhadap Pelajar dan Mahasiswa oleh BNN dan pihak yang terkait lebih bersifat Penyuluhan - Penyuluhan Hukum diantaranya Penyuluhan Sadar Narkoba khususnya untuk Pencegahan Narkoba [3] .Tim Pengabdian Masyarakat UMN Al Washliyah melakukan Pengabdian Untuk memberikan pengetahuan tentang penerapan Double Track Sistem Terhadap Pelaku Penyalahgunaan Narkotika kepada Remaja/Masyarakat yang ada di Desa Bandar Sono. Pencegahaan merupakan salah satu upaya untuk tidak melakukan/menggunakan barang haram ini yang merupakan bagian dari usaha dan Program Pemerintah untuk mengurangi pelaku kejahatan Narkoba ini.

Hasil Dari Kegiatan Pengabdian Kepada Masyarakat Ini Dapat Dilihat Dalam Skema

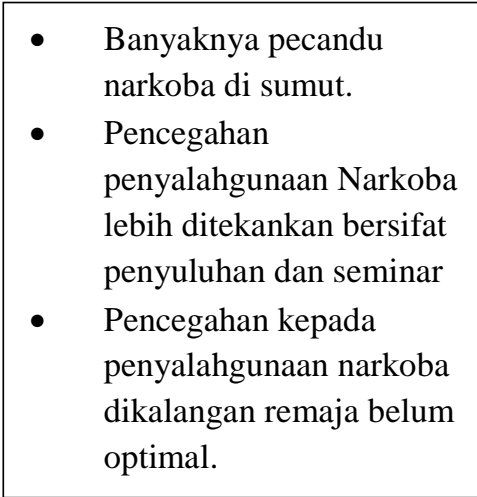

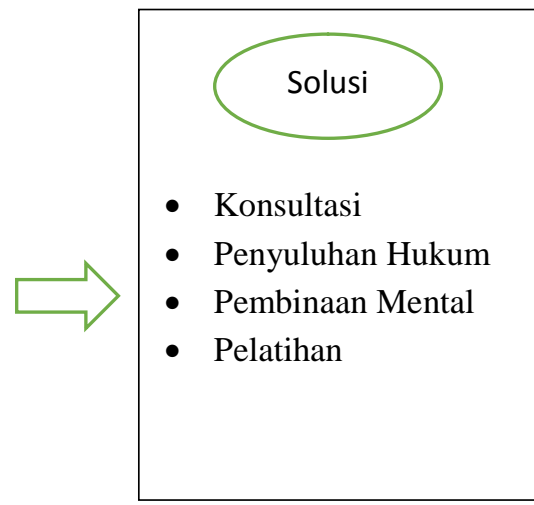

Gambar 1. Hasil Dari Kegiatan Pengabdian Kepada Masyarakat

\section{KESIMPULAN}

Yang Merupakan Kesimpulan Antara Lain :

1. Dengan .Melaksanakan Kegiatan Penyuluhan Hukum maka akan intensif dilaksanakan kegiatan pengabdian kepada masyarakat di Desa Bandar Sono Kabupaten
Batu Bara ini sesuai dengan kebutuhan dari masyarakat terutama terkait dengan Pencegahan Penyalahgunaan Narkotika ini akan dapat meningkatkan pemahaman masyarakat yang terkait dengan hal ini.. 
2. Melaksanakan Gerakan Kampanye menolak penyalahgunaan Narkotika sudah menjadi Program Pemerintah di Indonesia pada umumnya dan Sumatera Utara pada khususnya Penyalahgunaan Narkotika merupakan kategori sebuah tindak kejahatan yang luar biasa (extraordinary crime), oleh karena itu perlu ditangani secara intensif.

\section{SARAN}

Antara Lain :

1. Diharapakan kedepannya dengan melakukan Sosialisasi yang terkait dengan Double Track Sistem ini bisa di bangun Pusat Rehabilitasi Di Desa Bandar Sono Kabupaten BatuBara ini.

2. Diharapkan tetap intens mengadakan Sosialisasi dengan Pemahaman Bahaya dari Narkoba ini Kepada Masyarakat Di Desa Bandar Sono Kabupaten Batu Bara ini.sebagai dasar untuk meminimalkan penyalahgunaan Narkotika di Daerah ini.

\section{REFERENSI}

Forum, Virus Jahat Bernama Narkotika, 30 Desember 2001. Waspada, Anggota DPR RI Prihatin Sumut Ranking 3 Pemakai Narkoba, 28 Pebruari 2015

Eva Achjani Zulfa, Indrianto Seno Adji, Pergeseran Paradigma Pemidanaan, Lubuk Agung, 2011

Peredaran Narkoba Di Tanjung Tiram,metatelinga.com.Berita Sumut, 19 Januari 2017.

Undang-Undang RI Nomor 35 Tahun $2009 \quad$ Tentang Narkotika, Undang-Undang RI Nomor 5 Tahun 1997 Tentang Psikotropika, Pustaka Mahardika, 2011 